\title{
Applying School Administrators' Authentic Leadership Skills in Conflict Situations: The Perceptions of Substitute Teachers
}

\author{
Seyithan Demirdag*, Sezai Kalafat \\ Department of Educational Sciences, Bulent Ecevit University, Turkey
}

Copyright $(2016$ by authors, all rights reserved. Authors agree that this article remains permanently open access under the terms of the Creative Commons Attribution License 4.0 International License.

\begin{abstract}
This study mainly aimed to determine the relationships between conflict management strategies and authentic leadership attitudes of primary school administrators based on the perception of substitute teachers, who were in pedagogical proficiency classes at a university. This quantitative study included 456 substitute teachers. Two instruments were used for data collection. Authentic Leadership Questionnaire (ALQ) was used to examine primary school administrators' authentic leadership levels and Rahim Organizational Conflict Inventory-II (ROCI-II) was used to examine their conflict management levels based on the perceptions of substitute teachers. The data was analyzed based on the descriptive statistics, correlations, and regression analyses. The findings of the study showed that administrators' leadership levels were the highest on Self-Awareness (SEAW) and the lowest on Relational Transparency (RETR). In addition, their conflict management levels were the highest on Dominating (DO) and the lowest on Avoiding (AV). The results also suggested that there were significantly low levels of relationships between primary school administrators' conflict management strategies and authentic leadership attitudes. Lastly, based on the findings from regression analyses, the variables constituting the subscales of ALQ predicted quite low percentages of variances in ROCI-II's subscales.
\end{abstract}

Keywords Authentic Leadership, Conflict Management, Substitute Teachers, School Administrators

\section{Introduction}

While recent legislations in many developed countries mandate that all teachers must be highly qualified in their areas of teaching, there are no such requirements for substitute teachers. In a developed country such as the USA, being a permanent classroom teacher requires taking graduate level courses such as classroom management, learning theories, reading instruction, and math instruction. After taking these courses, new teachers will have to practice their theoretical knowledge under the guidance of a master teacher. On the other hand, substitute teachers are not required to have any educational training or experience. Nevertheless, school districts with sufficient funds are willing to provide training for substitute teachers. As a consequence, lack of training and experience may put these teachers in the center of blames of permanent teachers and school administrators. Such ill-treatments may jeopardize substitute teachers' quality of teaching.

The demand for substitute teachers has increased due to absentee rate of permanent teachers. Research suggests that students in the USA spend at least 10 percent of a school year being instructed by a substitute teacher [43]. This finding indicates that from K-12 grades, students are being taught under the guidance of substitute teachers. So, this suggests that at least eight percent of students in the USA, spend valuable instructional times with substitute teachers [14]. In line with this, it is inevitable to accept that substitute teachers have been an integral part of the educational process. Therefore, the treatment of their superiors such as school principals may have a substantial impact on their teaching and motivation.

In a developing country such as Turkey, it is estimated that the number of substitute teachers is about 11 percent of permanent school teachers [31]. Most of these substitute teachers are alternatively certified through pedagogical proficiency classes provided by colleges of education. According to data from MEB [31], Turkish schools still need more than 120 thousands permanent teachers. The gap associated with permanent teachers in Turkish schools has been covered by substitute teachers. Compared to substitute teachers in the USA, such teachers go through similar problems in Turkey as well. As they do not receive proper training, in many cases they may be required to teach courses other than their areas of specialties. This situation decreases their levels of self-efficacy and self-trust as many of them do not receive proper training on classroom management or 
conflict management strategies. In addition, lack of support from their colleagues and leadership from their administrators may worsen their quality of teaching or enthusiasm towards increasing student achievement.

\subsection{Authentic Leadership}

Being authentic is all about being consistent about knowing oneself on individual base [4]. Authentic leaders are committed to understand what sorts of drivers about their purpose, integrity, values, and relationships are important in such attitudes [e.g., 16, 28]. The world needs authentic leaders, who are the stable forces in effecting people's life [3]. It is evident that authentic leaders encourage positive leadership actions throughout the organizations [e.g., 19, 30]. Research suggests that authenticity in leadership promotes team work, engagement, and increased culture [e.g., 13, 28]. In addition it prevents victimization and bullying in an organization [e.g., 3, 15].

There are several theories on authentic leadership; however, most of them rely on Kernis's [23] theoretical framework, which defines the concept of authenticity as a person's true self or his uninhibited behavior. Kernis [23] suggests that authentic leaders are aware of their feelings, thoughts, manners, and character traits and take actions accordingly in certain situations. The characteristic features of authentic leaders may expose their real attitudes while facing conflict situations. Therefore, the thoughts and feelings of authentic leaders may have an effect on how they would be willing to find a resolution in chaotic conditions. Authentic leaders would eventually possess the capacity of developing meaningful exchanges with their colleagues and followers [e.g., 11, 35]. Such exchanges would result in more productive working environments [e.g., 13, 28, 4]. Having authentic leaders in organizational settings may create a reflection of trustworthiness as well as strong connections [34]. The actions and behaviors of these leaders are consistent with their beliefs and attitudes. Authentic leaders are needed in many situations including crises occurring in a work environment [10]. They would use their critical reasoning and positive psychological capacities to find substantial solutions for the problems causing crises [1]. Moreover, leaders' balanced processing capacities will help people to be aware of their problem solving potentials in order to be involved in decision making processes [41].

Preparing leaders for K-12 schools has been the focal point of discussions in educational settings. Having school principals with lack of leadership skills may have negative impacts on both permanent and substitute teachers [24]. Stakeholders in education believe that school principals, who have difficulty in dealing with conflict situations, may be the main reasons for negative school climate and culture [12]. Although school reforms mainly focus on improving the quality of teaching and learning, teachers, students and parents are aware of the fact that the quality of education is heavily relied on the quality of leadership skills of school administrators [33]. Improving student learning necessitates the existence of authentic leaders, who are able to encourage all teachers and students for collaboration, motivation and communication in schools where the overall culture is positive [e.g., $36,42,46$ ].

\subsection{Conflict Management}

Conflicts include situations where individuals start having substantial differences on ideas, values, interests, or beliefs [7]. Conflict management creates difficulties for certain individuals or groups when people in charge tend to take customary measures about the conflict itself [27]. Therefore, this process may be destructive rather than being handled in a positive problem solving manner. Although most research conducted on conflict management is about traditional organizations, it is crucial to point out that educational institutions are free from conflict situations [32]. Due to the characteristics of academic departments, conflict situations in educational institutions may be irrepressible. These conflicts may be between school principals or all teachers and between permanent teachers or substitute teachers, and between teachers or students [20].

In literature, several ways of handling conflicts are outlined; however, research mainly relies on Dual Concern Theory, which was proposed by Blake and Mouton [6] Later on, the theory was revised by Rahim [39] and Pruitt and Rubin [38]. The theory basically suggests that conflict management is a combination of low or high concerns either for self or others [e.g., 40, 44]. In addition, it suggests that solution of the problems may be possible when individuals or groups tend to be open, exchange information, and examine the differences between one another [e.g., 25, 37].

It is important to indicate that conflicts may create situations for teachers' and students' growth. However, when not handled well, it may be harmful and prevent student learning as well as teacher-teacher and administrator-teacher collaboration, which may have a substantial impact on a school' learning and leadership culture [e.g., 18, 45]. Conflicts in schools may occur based on several reasons: lack of communication and openness, authority issues, expectations, responsibilities, resentments, and misunderstandings [e.g., 5, 18, 26]. Additionally, coming from different cultural backgrounds or having different worldviews may also be the reasons of conflict among educators and school leaders [45]. Some school administrators may find it extremely difficult to include both permanent and substitute teachers in decision making processes regarding student success and school related events [2]. Such treatment would only create a negative teaching and learning environment for students, teachers, and administrators [29]. Research suggests that leaders in education may be successful in conflict management when they have commitment to identify and understand the issues preventing teachers from teaching and students from learning [e.g., 5, 22]. 
Although there are many studies on authentic leadership and conflict management strategies, most of the studies are related to traditional organizational settings. Those, which are conducted in educational settings mainly focus on permanent teachers, school administrators, parents, or students. Research is lacking about the authentic leadership and conflict management strategies of primary schools' administrators based on the perceptions of substitute teachers. Thus, the present study is believed to fill this gap in the literature.

\subsection{Purpose of the Study}

The aim of this study was to determine the relationship between conflict management strategies and authentic leadership of school principals based on the perception of substitute teachers. To achieve this goal, the following research questions were asked:

1. What are the perceptions of substitute teachers about primary school administrators' authentic leadership and conflict management strategies?

2. How do the perceptions of substitute teachers about primary school administrators' authentic leadership and conflict management strategies differ based on their genders?

3. What are the relationships between primary school administrators' authentic leadership and conflict management strategies based on the perceptions of substitute teachers?

4. Do school administrators' conflict management strategies predict their authentic leadership behaviors?

\section{Methodology}

This quantitative study was designed as a relational descriptive model to examine the relationships between school administrators' authentic leadership and conflict management strategies. The relational descriptive model was used to explain the level and existence of relationships between variables that have associations between past and current situations [21].

\subsection{Sample}

The participants of the study included substitute teachers attending a university's alternative certification program in Zonguldak province, Turkey to become permanent teachers in their schools. They were selected through non-random selection. There were 456 substitute teachers in the sample to examine the authentic leadership and conflict management strategies of the primary school administrators. Out of 456 participants, there were 268 (58.8\%) female substitute teachers and $188(41.2 \%)$ male substitute teachers. Years of teaching experiences were 1-2 years for 208 (45.6\%) participants, 3-4 years for $106(23.3 \%)$ participants, 5-6 years for 99 (21.7\%), and 7 years and more for $43(9.4)$ participants (see Table 1).

Table 1. Distribution of Substitute Teachers According to Their Genders \& Teaching Experiences

\begin{tabular}{|c|c|c|c|c|}
\hline \multirow{2}{*}{ Gender } & \multicolumn{4}{|c|}{ Female: $268(58.8 \%)$} \\
\cline { 2 - 5 } & \multicolumn{4}{|c|}{ Male: $188(41.2 \%)$} \\
\hline \multirow{2}{*}{$\begin{array}{c}\text { Teaching } \\
\text { Experience }\end{array}$} & $1-2$ years & $3-4$ years & $5-6$ years & $\begin{array}{c}7 \text { years } \\
\text { and more }\end{array}$ \\
\cline { 2 - 5 } & $208(45.6 \%)$ & $106(23.3 \%)$ & $99(21.7 \%)$ & $43(9.4 \%)$ \\
\hline
\end{tabular}

\subsection{Data Collection Tools}

The study included two data collection instruments. Each instrument had questions about participants' demographics including their genders and teaching experiences. The first instrument, Authentic Leadership Questionnaire (ALQ) was used to examine primary school administrators' authentic leadership levels based on the perceptions of substitute teachers. The second instrument, Rahim Organizational Conflict Inventory-II (ROCI-II) was used to examine the conflict management levels of primary school administrators based on perceptions of substitute teachers.

ALQ, was originally developed by Gardner et al. [13] and adapted to Turkish by Çeri-Booms [9]. This five-point (Strongly Disagree-1 to Strongly Agree-5) Likert type scale included 16 items. The scale included four subscales: Self Awareness (SEAW-4 items), Unprejudiced Assessment (UNAS-3 items), Relational Transparency (RETR-5 items), and Ethics (ET-4 items). The validity and reliability studies of the scale were done by Çeri-Booms [9] as the Cronbach's Alpha internal consistency coefficient of $\alpha$ was .81 . The reliability coefficients were estimated again using the data obtained in the present study, which revealed reliable results, $\alpha=.71$ for SEAW; $\alpha=.77$ for UNAS; $\alpha=.75$ for RETR, and $\alpha=.78$ for ET.

ROCI-II, was originally developed by Rahim [39] and adapted to Turkish language by Gümüşeli [17]. This five-point (Strongly Disagree-1 to Strongly Agree-5) Likert type scale included 28 items. The scale was designed to measure five dimensions of conflict management strategies: Integrating (IN-7 items), Obliging (OB-6 items), Dominating (DO-5 items), Avoiding (AV-6 items), and Compromising (CO-4 items). The validity and reliability studies of the scale were done by Gümüşeli [17] as the Cronbach's Alpha internal consistency coefficient of $\alpha$ was .80 . The reliability coefficients were estimated again using the data obtained in the present study, which revealed reliable results, $\alpha=.77$ for IN; $\alpha=.72$ for OB; $\alpha=.72$ for $\mathrm{DO}, \alpha=.75$ for $\mathrm{AV}$, and $\alpha=.72$ for $\mathrm{CO}$.

\subsection{Data Analysis}

The independent variables in the study were "gender" and "experience" and the dependent variables were "authentic leadership" and "conflict management strategies" of primary school administrators based on the perceptions of substitute teachers. The analysis of the study was made in 
a pattern revealing the effects of independent variable on the dependent variables as well as the relationships between dependent variables. The SSPS 20.0 package program was used for data analyses. For the analysis, first, mean scores of each subscale were determined based on the following calculations: 1.00-1.80 (absolutely disagree), 1.81-2.60 (disagree), 2.61-3.40 (neutral), 3.41 to 4.20 (agree), and 4.21 to 5.00 (strongly agree). To detect the levels of authentic leadership and conflict management levels of primary school administrators based on the genders of substitute teachers, independent samples t-test was adopted. The association between dependent variables was estimated using Pearson correlation coefficient (r). According to Büyüköztürk [8], the correlation coefficients may be interpreted according to the following values: .70-1.00 = high, .69-0.30 = moderate, and .29-.00 = low. Lastly, Multiple Linear Regression Analysis was used to analyze how much of independent variables predict the dependent variables. The standardized Beta $(\beta)$ coefficients and the t-test results regarding their significance were considered. The significance coefficient, $\mathrm{p}$ was set at .05 for the statistical analyses made in the study.

\section{Results}

Study findings and their interpretations are presented in this section of the study. The independent sample t-test was conducted to determine the authentic leadership and conflict strategy levels of primary school administrators based on the genders of substitute teachers (see Table 2). The results showed that there were no significant differences on ALQ total scores and ROCI-II total scores based on the genders of substitute teachers $(\mathrm{p}>.05)$.
Table 2. Authentic Leadership and Conflict Management Levels of Primary School Administrators Based on the Genders of Substitute Teachers

\begin{tabular}{|c|c|c|c|c|c|c|}
\hline Variables & Gender & $\mathrm{N}$ & Mean & SD & $t$ & $p$ \\
\hline \multirow{2}{*}{$\begin{array}{c}\text { ALQ Total } \\
\text { Score }\end{array}$} & Male & 188 & 3.57 & .30 & \multirow{2}{*}{.57} & \multirow{2}{*}{.56} \\
\cline { 2 - 5 } & Female & 268 & 3.55 & .32 & & \\
\hline \multirow{2}{*}{$\begin{array}{c}\text { ROCI-II Total } \\
\text { Score }\end{array}$} & Male & 188 & 3.64 & .25 & \multirow{2}{*}{1.44} & .15 \\
\cline { 2 - 5 } & Female & 268 & 3.61 & .23 & & \\
\hline$p<.05$
\end{tabular}

The results of descriptive statistics (means and standard deviations) and correlation coefficients are presented in Table 3. Based on the results of descriptive statistics, the highest mean scores in terms of authentic leadership belonged to SEAW ( $\overline{\mathrm{X}}=3.62)$ subscale, while RETR $(\bar{X}=3.49$ ) had the lowest scores. In addition, the perceptions of substitute teachers based on primary school's administrators conflict management levels were the highest on DO $(\overline{\mathrm{x}}=3.76)$ and the lowest on $\operatorname{AV}(\overline{\mathrm{x}}=3.33)$.

The Pearson Correlation Coefficient technique was used to ascertain the relationships between primary school administrators' authentic leadership and conflict management levels based on the perceptions of substitute teachers (see Table 3). Based on the results, there were not significant relationships between all subscales of ALQ and ROCI-II. However, as a subscale of ALQ, RETR had meaningful relationships with $\mathrm{IN}, \mathrm{OB}, \mathrm{AV}$, and $\mathrm{CO}$ as the subscales of ROCI-II. The correlations were low and significant. When inter-correlations between these subscales were analyzed, the correlation between RETR and IN was negative and significant $(\mathrm{r}=-.19, \mathrm{p}<.01)$. There was a positive and significant correlation between RETR and OB $(\mathrm{r}=.11, \mathrm{p}<.01)$. In addition, there was a significant and negative correlation between RETR and AV ( $r=-.16$, $\mathrm{p}<.01)$. Lastly, the correlation between RETR and CO was significant and positive $(\mathrm{r}=.10, \mathrm{p}<.01)$.

Table 3. Means. Standard Deviations and Correlation Coefficients for the Variables

\begin{tabular}{|c|c|c|c|c|c|c|c|c|c|c|c|}
\hline Variables & Mean & SD & 1 & 2 & 3 & 4 & 5 & 6 & 7 & 8 & 9 \\
\hline 1.SEAW & 3.62 & .57 & 1.00 & & & & & & & & \\
\hline $2 . \mathrm{RETR}$ & 3.49 & .63 & .06 & 1.00 & & & & & & & \\
\hline $3 . \mathrm{ET}$ & 3.53 & .52 & .00 & .05 & 1.00 & & & & & & \\
\hline $4 . \mathrm{UNAS}$ & 3.59 & .53 & -.07 & $.10^{*}$ & $.32^{*}$ & 1.00 & & & & & \\
\hline $5 . \mathrm{IN}$ & 3.48 & .49 & .04 & $-.19^{*}$ & -.01 & -.00 & 1.00 & & & & \\
\hline $6 . \mathrm{OB}$ & 3.64 & .58 & .08 & $.11^{*}$ & -.00 & -.02 & -.08 & 1.00 & & & \\
\hline $7 . \mathrm{DO}$ & 3.76 & .57 & -.00 & -.00 & .01 & -.06 & .03 & $.16^{*}$ & 1.00 & & \\
\hline $8 . \mathrm{AV}$ & 3.33 & .54 & -.04 & $-.16^{*}$ & -.00 & -.07 & .00 & -.01 & .00 & 1.00 & \\
\hline $9 . \mathrm{CO}$ & 3.93 & .50 & .02 & $.10^{*}$ & .02 & .05 & -.01 & -.01 & .01 & -.06 & 1.00 \\
\hline
\end{tabular}

$* p<.01$. 
Table 4. The Results of the Multiple Linear Regression Analysis for the Prediction of Authentic Leadership Based on Integrating

\begin{tabular}{|l|c|c|c|c|c|c|c|}
\hline Variables & B & SE & $\beta$ & $t$ & $p$ & Partial $\mathrm{r}$ & Part $\mathrm{r}$ \\
\hline (Constant) & 3.79 & .26 & - & 14.34 & .00 & - & - \\
\hline SEAW & .05 & .04 & .05 & 1.26 & .20 & .05 & .05 \\
\hline RETR & -.15 & .03 & -.19 & -4.23 & .00 & -.19 & -.19 \\
\hline ET & -.00 & .04 & -.00 & -.12 & .90 & -.00 & -.00 \\
\hline UNAS & .02 & .04 & .02 & .44 & .65 & .02 & .02 \\
\hline
\end{tabular}

$F=4.74 ; p<.01 ; R=.20 ; R^{2}=.04$.

Table 5. The Results of the Multiple Linear Regression Analysis for the Prediction of Authentic Leadership Based on Obliging

\begin{tabular}{|l|c|c|c|c|c|c|c|}
\hline Variables & $\mathrm{B}$ & $\mathrm{SE}$ & $\beta$ & $t$ & $p$ & Partial $\mathrm{r}$ & Part $\mathrm{r}$ \\
\hline (Constant) & 3.14 & .31 & - & 10.02 & .00 & - & - \\
\hline SEAW & .07 & .04 & .07 & 1.57 & .11 & .07 & .07 \\
\hline RETR & .10 & .04 & .10 & 2.31 & .02 & .10 & .10 \\
\hline ET & .00 & .05 & .00 & .02 & .97 & .00 & .00 \\
\hline UNAS & -.03 & .05 & -.03 & -.67 & .49 & -.03 & -.03 \\
\hline
\end{tabular}

$F=2.17 ; p<.01 ; R=.13 ; R^{2}=.01$.

Table 6. The Results of the Multiple Linear Regression Analysis for the Prediction of Authentic Leadership Based on Avoiding

\begin{tabular}{|l|c|c|c|c|c|c|c|}
\hline Variables & $\mathrm{B}$ & SE & $\beta$ & $t$ & $p$ & Partial $\mathrm{r}$ & Part $\mathrm{r}$ \\
\hline (Constant) & 4.06 & .29 & - & 14.01 & .00 & - & - \\
\hline SEAW & -.03 & .04 & -.03 & -.82 & .41 & -.03 & -.03 \\
\hline RETR & -.13 & .04 & -.15 & -3.35 & .00 & -.15 & -.15 \\
\hline ET & .03 & .05 & .03 & .60 & .54 & .02 & .02 \\
\hline UNAS & -.06 & .05 & -.06 & -1.32 & .18 & -.06 & -.06 \\
\hline
\end{tabular}

$F=3.71 ; p<.01 ; R=.17 ; R^{2}=.03$.

The results of the multiple linear regression analysis for the prediction of authentic leadership based on ROCI-II's subscale, IN are listed in Table 4. An examination of the results listed in this table demonstrates the statistical importance of the prediction equation measuring the extent to which the ALQ subscales predict the ROCI-II's IN subscale $(\mathrm{R} 2=.04, \mathrm{~F}=4.74, \mathrm{p}<.01)$.

The variables constituting the subscales of the ALQ predict $4 \%$ of the total variance in the ROCI-II's IN subscale. The relative importance of the predictive variables in the IN subscale according to the standardized regression coefficient $(\beta)$ is as follows: SEAW, UNAS, ET, and RETR, respectively. Analysis of the findings related to the statistical significance of the regression coefficients reveals that other than RETR subscale, the remaining of the ALQ subscales are not statistically significant predictors of the ROCI-II's IN subscale.

Table 5 represents the findings of the multiple linear regression analysis for the prediction of authentic leadership based on ROCI-II's subscale, OB. The results listed in Table 5 shows the statistical importance of the prediction equation measuring the extent to which the ALQ subscales predict the ROCI-II's OB subscale $\left(\mathrm{R}^{2}=.01, \mathrm{~F}=2.17, \mathrm{p}<.01\right)$.

The variables constituting the subscales of the ALQ predict only $1 \%$ of the total variance in the ROCI-II's OB subscale. The relative importance of the predictive variables in the IN subscale according to the standardized regression coefficient ( $\beta$ ) is as follows: RETR, SEAW, ET, and UNAS, respectively. Analysis of the results related to the statistical significance of the regression coefficients reveals that other than RETR subscale, the remaining of the ALQ subscales are not statistically significant predictors of the ROCI-II's OB subscale.

The results of the multiple linear regression analysis for the prediction of authentic leadership based on ROCI-II's subscale, AV are listed in Table 6. An investigation of the results listed in this table demonstrates the statistical importance of the prediction equation measuring the extent to which the ALQ subscales predict the ROCI-II's AV subscale $\left(\mathrm{R}^{2}=.03, \mathrm{~F}=3.71, \mathrm{p}<.01\right)$.

The variables constituting the subscales of the ALQ predict $3 \%$ of the total variance in the ROCI-II's AV subscale. The relative importance of the predictive variables in the IN subscale according to the standardized regression coefficient $(\beta)$ is as follows: ET, SEAW, UNAS, and RETR, respectively. Analysis of the findings related to the statistical significance of the regression coefficients reveals that other than RETR subscale, the remaining of the ALQ 
subscales are not statistically significant predictors of the ROCI-II's AV subscale.

\section{Discussion}

In this study, the relationships between conflict management strategies and authentic leadership behaviors of primary school administrators were examined based on the perceptions of substitute teachers. According to the results, one may suggest that authentic leadership behaviors of primary school administrators may not be considered important predictors of their conflict management strategies.

The results of research suggested that the leadership behaviors primary school administrators were mostly associated with SEAW. However, their leadership behaviors had the least association with RETR. This is consistent with the results of Avolio et al. [4], who reported that exhibiting authentic leadership behaviors were all about being consistent about knowing oneself on individual base. Considering that being self-transparent may include sharing not only positive and but also negative aspects of an individual to others, one may conclude that school leaders may feel reluctant to be self-transparent as it is likely that their negative approaches may negatively affect teachers' life in a school setting [16]. These results are also consistent with those by Avolio and Gardner [3], who indicated that although being self-transparent is about communicating openly to individuals, such attitude may include both positive and negative effects on others' life.

When the conflict management strategies of primary school administrators were examined, it was evident that their conflict management strategies were mostly associated with DO. Based on these results, it may be suggested that school leaders need to preserve a good standing and create strong grounds in order to find effective solutions for the problems associated with teaching and learning. In parallel research, Lindelow and Scott [27] indicated that people in charge may need to take rigorous measures to prevent crisis as such situations may be destructive for certain individuals or groups. That being said, the leaders may have to take dominating measures on issues to be effective problem solvers during the conflict situations [e.g., 7, 32].

On the other hand, the study results suggested that the conflict management strategies of primary school administrators had the least association with AV. Based on the results, it may be concluded that school leaders did not refrain from intervening conflict situations to exhibit their leadership skills. These results are consistent with the results of Miklas and Kleiner [32], who reported that as conflicts may be irrepressible in educational institutions, school leaders should not avoid to take strong actions to handle deteriorating issues with positive problem solving manners [20].

The results of the study showed that the primary school administrators' authentic leadership behaviors and conflict management strategies did not differ based on the genders of substitute teachers. These results suggest that authentic leaders are committed to have similar relationships regardless of their genders. Within similar results, Macik Frey et al. [28] found that authentic leaders seek to locate the crucial factors that help them to prevent crisis and understand how to establish a positive and productive working environment that embrace both males and females in the same setting. In similar studies, Harvey et al. [19] and McGuire et al. [30] suggested that authentic leaders have strong tendencies in creating and encouraging positive leadership actions throughout the organizations.

When the relationships between primary school administrators' authentic leadership and conflict management strategies based on the perceptions of substitute teachers were examined, it may be concluded that mostly, the subscales of ALQ and ROCI-II were not significantly inter correlated. However, it is viable to suggest that there were a few significantly low correlations between the subscales of ALQ and ROCI-II. When the subscales of ALQ and ROCI-II were examined, there was a negative and significant correlation between RETR and IN and RETR and AV. From such results, it may be indicated that as much as being transparent is one's true self to other people, school leaders may have fears of making substantial mistakes when showing interests in the concerns of other teachers. Likewise, Gümüşeli [18] along with Ustun and Seren [45] suggested that when school leaders fail to handle conflict situations in schools, the consequences may be harmful and prevent student learning as well as teachers' motivation and encouragement. On the other hand, although the relationship between RETR and AV was negative and significant in this study, Rahim [39] suggested otherwise. $\mathrm{He}$ indicated that if someone is unwilling about taking actions for other people's concerns, it may be concluded that they tend to refrain from conflict situations.

The study results also showed that the correlations between RETR and OB and RETR and CO were positive and significant. Based on such results, it may be suggested that school leaders, who feel obliged or tend to compromise in conflict situations have levels of concerns ranging from intermediate to low. This suggests that primary school administrators avoid creating misunderstandings or resentments among teachers [e.g., 5, 18, 26]. Additionally, Ustun and Seren [45] concluded that school leaders need to be aware of the fact and beware of intervening conflict situations that people in an organization may have different worldviews as they come from different cultures. As a result, the significant and fairly low correlations between authentic leadership and conflict management approaches of primary school administrators may imply that as school administrators exhibit some leadership skills, to some extent, they interfere with the concerns of teachers in order to find effective solutions.

Present research also found that most of the authentic leadership attitudes of primary school administrators were significantly predicted by $\mathrm{IN}, \mathrm{OB}$, and $\mathrm{AV}$ while $\mathrm{DO}$ and 
CO were non-significant predictors of ALQ. When the results of the multiple linear regression analysis for the prediction of IN subscale were examined, the findings showed that the predictive variables of ALQ were only able to explain $4 \%$ of the total variance in IN subscale. Thus, it can be concluded that although it was considered to be a low level, to some extent, the leadership attitudes of school administrators included cooperation, which included examination of differences and sharing of ideas between groups of teachers [2]. In addition, the results of the study indicated that the predictive variables of ALQ were only able to explain only $1 \%$ of the total variance in OB subscale. It may be concluded that such results may be possible when school leaders obtain less concern for teachers in their schools [37]. Lastly, when the results of the multiple linear regression analysis for the prediction of $\mathrm{AV}$ subscale were examined, the results suggested that the predictive variables of ALQ were only able to explain $3 \%$ of the total variance in AV subscale. Such findings may mean that school administrators were considered to be passive in showing concerns for teachers [e.g., 29, 39].

In conclusion, the present study examined the relationships between primary school administrators' authentic leadership attitudes and conflict management levels based on the perceptions of substitute teachers. Even though the results of this study showed that mostly, there were not any relationships between authentic leadership and conflict management strategies of school administrators, at some point, there were few indications of significantly low correlations between such variables. In this case, it may be concluded that school leaders act reluctantly to resolve crisis within school settings. Therefore, it would be a more appropriate approach for school administrators to demonstrate their authentic leadership skills to resolve conflicts occurred among substitute teachers due to lack of communication, authority issues, expectations, responsibilities, and misunderstandings. Otherwise their leadership attitudes would be confined within self and school itself without providing purely effective solutions that may affect teachers' teaching, which likely promotes student learning and creates a positive school climate.

\section{REFERENCES}

[1] M. Y. Akyüz. Çağdaş okulda etkili liderlik. Ege Eğitim Dergisi, 2(1), 109-119. 2002

[2] İ. H. Arslantaş, \& M. Özkan. Okul müdürlerinin çatışma çözmede yapıc1-yıkıcı olmaları ile öğretim liderliği arasındaki ilişki. Dumlupınar Üniversitesi Sosyal Bilimler Dergisi, 34(11), 231-240. 2012

[3] B. J. Avolio, \& W. L. Gardner. Authentic leadership development: Getting to the root of positive forms of leadership. The Leadership Quarterly, 16(3), 315-338. 2005

[4] B. J. Avolio, W. L. Gardner, F. O. Walumbwa, F. Luthans, \&
D. R. May. Unlocking the mask: A look at the process by which authentic leaders impact follower attitudes and behaviors. The Leadership Quarterly, 15(6), 801-823. 2004

[5] A. Bilgin. Catıșma çözme taktikleri: Bir ölçek geliștirme çalışması. Uludăg Üniversitesi Eğitim Fakültesi, 13(1), 85-94. 2000

[6] P. R. Blake, \& J. S. Mouton. Managerial grid. Houston. TX: Gulf. 1964

[7] W. Boonsathorn. Understanding conflict management styles of Thais and Americans in multinational corporations in Thailand. International Journal of Conflict Management, 18 (3), 196-221. 2007

[8] S. Büyüköztürk. Sosyal bilimler için veri analizi el kitabı [Handbook of data analysis for the social sciences] (2nd ed.). Ankara: Pegem A Yayıncılik. 2002

[9] S. M. Çeri-Booms. An empirical study on transactional transformational and authentic leaders: Exploring the mediating role of "trust in leader" on organizational indetification (Unpublished Doctoral Thesis). Yeditepe University Graduate Institute of Social Sciences. İstanbul. Retrieved from https://tez.yok.gov.tr/UlusalTezMerkezi. 2009

[10] S. Connock, \& T. Johns. Ethical leadership. London: Cromwell Pres. 1995

[11] R. L. Daft. The leadership experience (4. Baskl). Mason: Thomson Learning Inc. 2008

[12] S. Davis, L. Darling-Hammond, M. LaPointe, \& D. Meyerson. Developing successful principals: School leadership study, review of research. Stanford University Educational Leadership Institute, Stanford, CA. 2005

[13] W. L. Gardner, B. J. Avolio, F. Luthans, D. R. May, \& F. Walumbwa. Can you see the real me? A self-based model of authentic leader and follower development. The Leadership Quarterly, 16(3), 343-372. 2005

[14] R. S. Glass. Subs looking for a little respect. American Teacher, 85(8), 8. 2001

[15] Goffee. Managing authenticity: The paradox of great leadership-Respond. Harvard Business Review, 84(5), 151-151. 2006

[16] S. L. Grover, \& R. H. Moorman. Grasping the meaning and interpretation of integrity in business leadership. European Management Journal, 25(3), 167-170. 2007

[17] A. İ. Gümüşeli. İmir ortaöğretim okullart yöneticilerinin ögretmenler ile aralarındaki çatışmalar yönetme biçimleri (Yayımlanmamış doktora tezi). Ankara Üniversitesi. Ankara. Retrieved from https://tez.yok.gov.tr/UlusalTezMerkezi. 1994

[18] A. İ. Gümüșeli. İlköğretim okulu müdürlerinin çatışma yönetim stilleri ile öğretmenlerin iş doyumu arasındaki ilişki. Y.T.Ü. Fen Edebiyat Fak. İstanbul. 2001

[19] P. Harvey, M. J. Martinko, \& W. L. Gardner. Promoting authentic behavior in organizations: An attributional perspective. Journal of Leadership and Organizational Studies, 12(3), 1-11. 2006

[20] S. A. Holton. And now the answers! How to deal with conflict in higher education. New Directions for Higher Education, 1995(92), 79-89. 1995 
[21] N. Karasar. Bilimsel araștırma yöntemi (19. Baskı). Ankara: Nobel Yayınları. 2010.

[22] E. Karip. Çatışma yönetimi. Pegem Akademi. 2010

[23] M. H. Kernis. Toward a conceptualization of optimal self-esteem. Psychological Inquiry, 14, 1 - 26. 2003

[24] J. Keskin, \& N. A. Ayyıldız. Liderlik yaklaşımlarında yeni perspektifler: Pozitif ve otantik liderlik. Ege Akademik Bakış Dergisi, 8(2), 729-754. 2008

[25] T. Koçel. İşletme yöneticiliği. Yön Ajans. İstanbul. 1989

[26] M. Konak, \& M. Erdem. Öğretmenlerin görüşlerine göre ilkokul yöneticilerinin etik liderlik davranışları ile çatışma yönetme stratejileri arasındaki ilişki. Kuram ve Uygulamada Eğitim Yönetimi, 21(1), 69-91. 2015

[27] J. Lindelow, \& J. Scott. Managing conflict in school leadership. Education Resources Information Center clearing house: Educ. Manage. University of Oregon. 1989a

[28] M. Macik - Frey, J. C. Quick, \& C. L. Cooper. Authentic leadership as a pathway to positive health. Journal of Organizational Behavior, 30(3), 453-458. 2009

[29] J. Mahon. Conflict style and cultural understanding among teachers in the western United States: Exploring relationships. International Journal of Intercultural Relations, 33, 46-56. 2009

[30] D. McGuire, R. Todnem By, \& K. Hutchings. Towards a model of human resource solutions for achieving intergenerational interaction in organisations. Journal of European industrial training, 31(8), 592-608. 2007

[31] MEB Şubat'ta 30 bin öğretmen ataması müjdesi. Retrieved from http://www.meb.gov.tr/subatta-30-bin-ogretmen-atamasi-muj desi/haber/9788/tr\#. 2006

[32] E. J. Miklas, \& B. H. Kleiner. New developments concerning academic grievances. Management Research News, 26(2/3/4), 141-147. 2003

[33] J. Murphy. Preparing school leaders: Defining a research and action agenda. Lanham. MD: Rowman and Littlefield Publishers. Inc. 2006
[34] P. G. Northouse. Leadership: Theory and practice (5th ed.). Thousand Oaks. C. A.: SAGE Publications. 2010

[35] M. M. Novicevic, M. G. Harvey, M. Ronald, \& J. A. Brown-Radford. Authentic leadership: A historical perspective. Journal of Leadership and Organizational Studies, 13(1), 64-76. 2006

[36] K. O’Neill, B. Fry, G. Bottoms, \& S. Walker. Schools need good leaders now: State progress in creating a learning-centered school leadership system. Atlanta. GA: Southern Regional Education Board. 2007

[37] A. Y. Özdemir, \& A. Özdemir. Duygusal zeka ve çatışma yönetimi stratejileri arasındaki ilişkilerin incelenmesi: Üniversitede çalışan akademik ve idari personel üzerine uygulama. Selçuk Üniversitesi Sosyal Bilimler Enstitüsü Dergisi, 18, 393-410. 2007

[38] D. G. Pruitt, \& J. Rubin. Social conflict: Escalation. Stalemate and settlement. New York: Random House. 1986

[39] M. A. Rahim. A measure of styles of handling interpersonal conflict. Academy of Management journal, 26(2), 368-376. 1983

[40] M. A. Rahim. Managing conflict in organizations (3rd ed.). Westport. Connecticut: Quorum Books. 2001

[41] İ. Sezgül. Liderlik ve etik: Geleneksel. modern ve postmodern liderlik tanımları bağlamında bir değerlendirme. Toplum Bilimleri Dergisi, 4(7), 239 - 251. 2010

[42] R. J. Starratt. Ethical leadership (Vol. 8). Jossey-Bass. 2004

[43] S. Sykes. Substitutes teach 6.4 percent of classroom time. The Salt Lake Tribune B. 3.2002

[44] F. Tutzauer, \& M. E. Roloff. Communication processes leading to integrative agreements: Three paths to joint benefits. Communication Research, 15, 360-380. 1988

[45] B. Ustun, \& S. Seren. Conflict resolution skills of nursing students in problem-based compared to conventional curricula. Nurse Education Today, 28, 393-400. 2008

[46] E. Y1lmaz. Etik liderlik ölçeğinin geçerlilik ve güvenirlilik çalışması. Denizli XIV. Ulusal Eğitim Bilimleri Kongresi. 28-30 Eylül. Denizli. 2005 